\title{
Mapping Honeysuckle Distribution in Large Forests through Use of High Resolution Satellite Images - Case Study at Great Parks of Hamilton County, Ohio, USA
}

\author{
Hongmei Wang ${ }^{1, *}$, Spencer Taylor ${ }^{1}, B_{\text {Bret Henninger }}^{2}$, Margaret Minzner ${ }^{2}$, Ben Braeutigam², \\ Jessica Spencer \\ ${ }^{1}$ Department of Computer Science, Northern Kentucky University, United States \\ ${ }^{2}$ Winton Woods Office, Great Parks of Hamilton County, United States
}

Copyright $\bigcirc 2019$ by authors, all rights reserved. Authors agree that this article remains permanently open access under the terms of the Creative Commons Attribution License 4.0 International License

\begin{abstract}
A non-native invasive shrub, named Amur honeysuckle, has caused various problems to the habitats of native plants and animals. Local governments, private landowners and non-profit groups spend numerous efforts on removing these species from forests. The first step to remove the species is to know their spatial distribution. The major objective of this study is to explore how to quickly map honeysuckle distribution by using high resolution satellite images. The case study is located in Great Parks of Hamilton County (GPHC), Ohio. A World-View2 satellite image acquired on Nov. 9th 2013 was classified into several land use types, including low density honeysuckle area, medium/high density honeysuckle area, grass/crop, bare soil/construction, and water/wet land. Half of the field data that we collected in Nov. 2013 and some high resolution aerial photos (with 4 inch spatial resolution) were used to validate the classification result. The study result demonstrates that the World-View2 image delineates honeysuckle distribution fairly well, in particular, for medium/high density honeysuckle areas. As a pilot program utilizing advanced geospatial analysis, this project will provide important information for understanding the status of wildlife habitats and for implementing site-specific management in parks and nature preserves.
\end{abstract}

Keywords Amur Honeysuckle, Remote Sensing, High-resolution, Satellite Images, Aerial Photos, Classification

\section{Introduction}

Amur honeysuckle, a non-native tall shrub, has been a big natural resource challenge for many parks and nature preserves in the United States. This species was introduced into the United States in 1898 (Luken, 1988) and becomes widely cultivated in the eastern forests. It causes various problems to the native species habitat (Pimentel, Lach, Zuniga, \& Morrison, 2000). Control efforts spend hundreds of thousands of dollars on Amur honeysuckle removal and management every year.

The first step toward removing the honeysuckle is to know where they are located. Obviously, it is not practical to map out their distribution in the large forest through field survey. Remote sensing techniques can provide an alternative method, a more cost-efficient way to delineate the honeysuckle distribution in a large forest area.

Remote sensing data record the electromagnetic light energy reflected or emitted by the earth surface. Structures of plants on the earth surface and their interaction with electromagnetic radiation directly influence how leaves and plant canopies appear spectrally (Jensen, 2006). Vegetation objects have their unique spectral features different from other objects, such as high radiance difference between red and near-infrared spectral regions (Huete, 2004). Spectral vegetation indices (VI) calculated based on these radiances are directly related to the intercepted fraction of photosynthetically active radiation (Asrar, Fuchs, Kanemasu, \& Hatfield, 1984; Gallo \& Daughtry, 1986). The spectral characteristics of photosynthetically and non-photosynthetically active vegetation are obvious different, which can be utilized to estimate forage quantity and quality of vegetation (Beeri, Phillips, Hendrickson, Frank, \& Kronberg, 2007). Therefore, the vegetation can be identified from remote sensing imagery according to their unique spectral characteristics. 


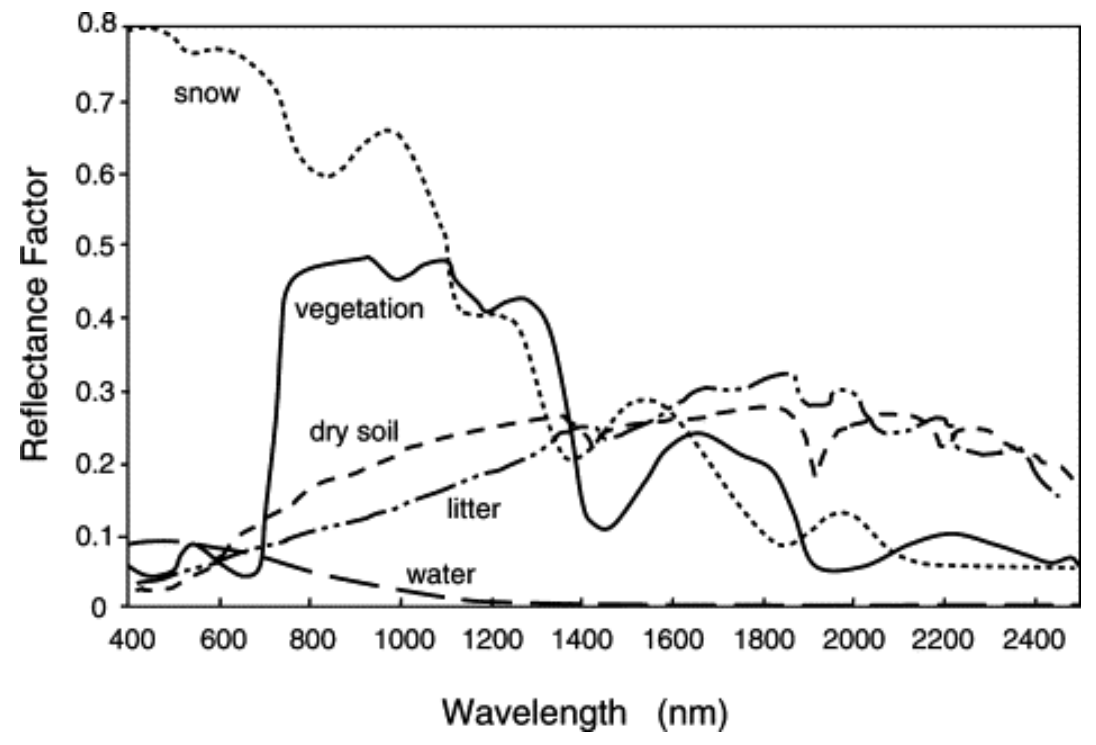

Figure 1. Spectral Reflection of Vegetation at Electromagnetic Channels (Huete, 2004)

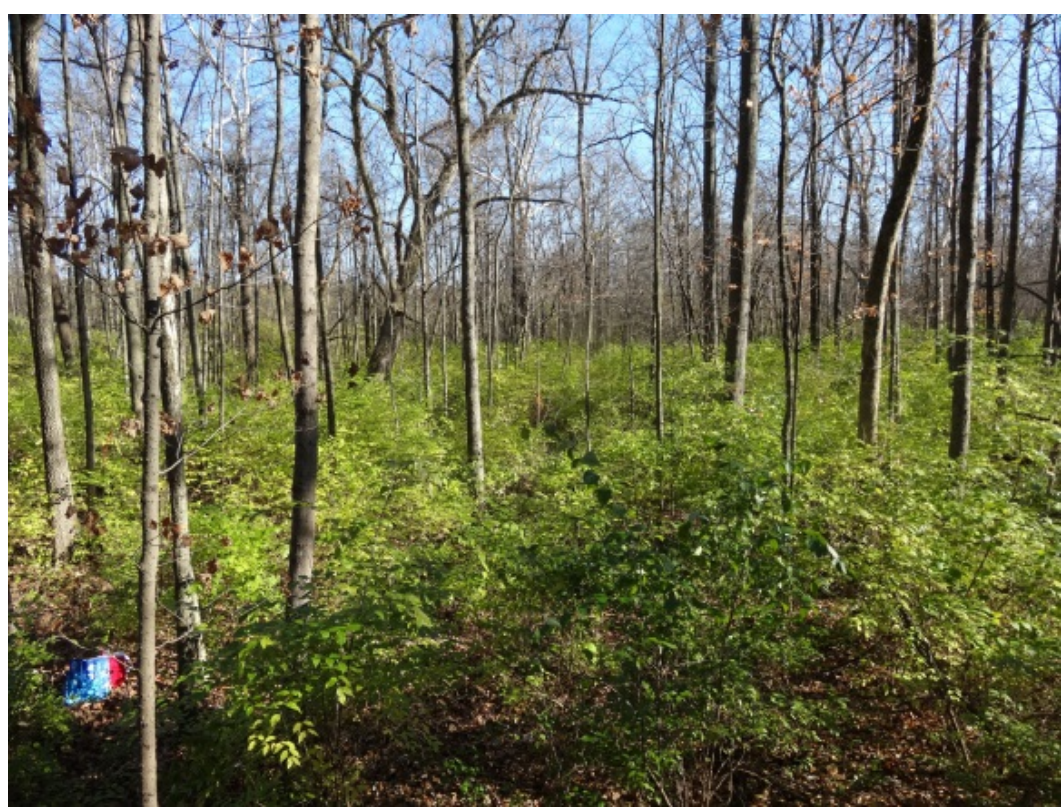

Figure 2. Armur Honeysuckle Taken on Nov. 9th, 2013 in Winton Woods, Ohio, USA

Amur honeysuckle becomes green earlier and retains green later than native woody species (Wilfong, Gorchov, \& Henry, 2009). In late fall, there is a time period when honeysuckle is the only green vegetation while most overstory trees are leafless (Figure 2). This unique leaf phenology of honeysuckle makes it possible to use satellite images to detect distribution of honeysuckle in forests (Resasco, Hale, Henry, \& Gorchov, 2007).

This study explores how to map honeysuckle distribution by using remote sensing techniques. The test field covers several parks in Great Parks of Hamilton County (GPHC), Ohio, USA (see Figure 3). The GPHC parks are on the front of an advancing honeysuckle invasion. High-resolution satellite imagery thus plays a better role in detecting its distributions at higher accuracies for practical management.

In this study, a World-View2 satellite image acquired on Nov. 9th 2013 was classified into several land use types, including low density honeysuckle area, medium/high density honeysuckle area, grass/crop, bare soil/construction, and water/wet land. The study result demonstrates that high resolution satellite images can delineate honeysuckle distribution fairly well, in particular, for medium/high density honeysuckle areas. As a pilot program utilizing advanced geospatial analysis, this study provides important information for understanding the status of wildlife habitats and for implementing site-specific management in parks and nature preserves. 

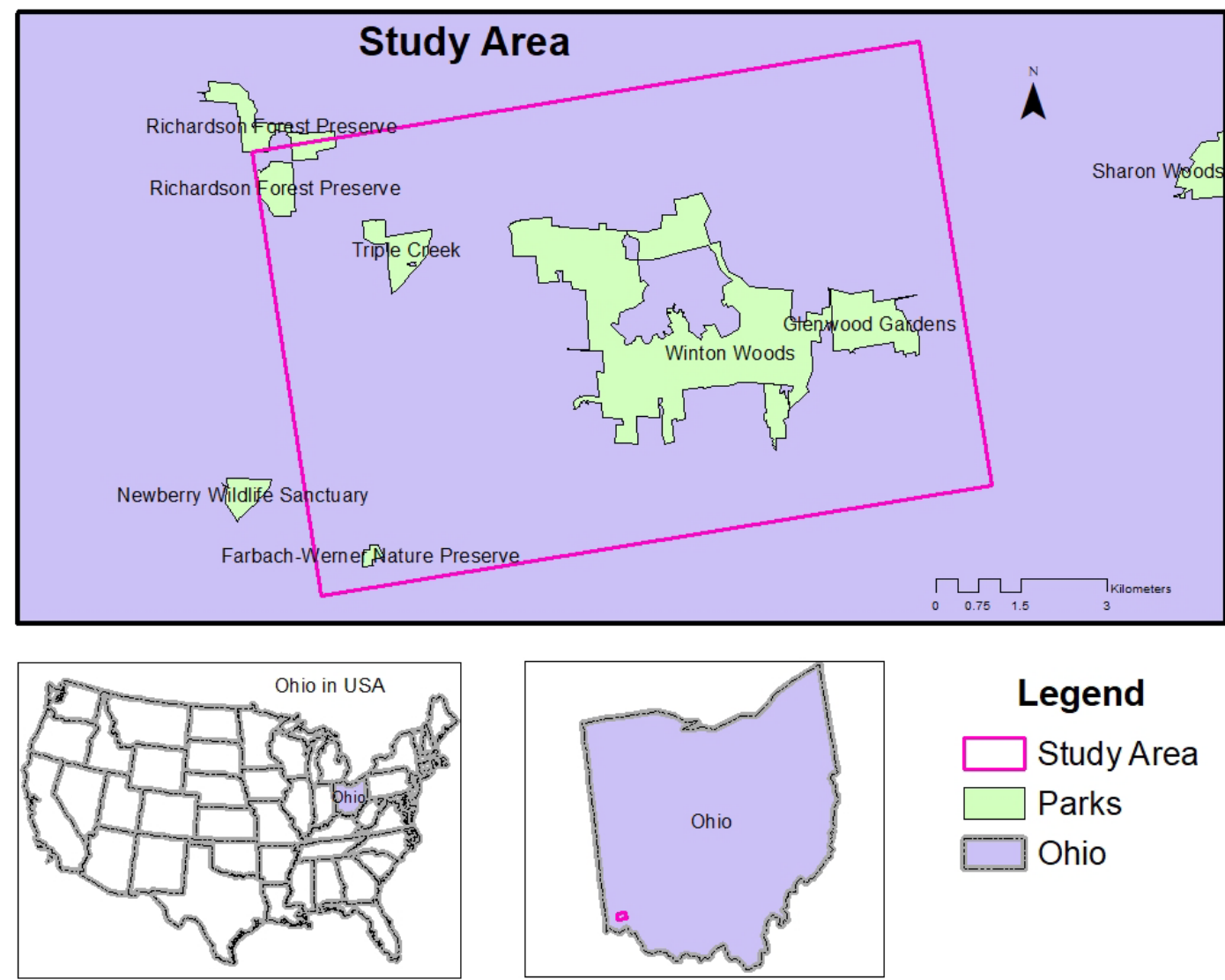

Legend

Study Area

Parks

Ohio

Figure 3. Study Area in Great Parks of Hamilton County, Ohio, USA

\section{Previous Studies}

Over the past half century, remote sensing imagery with various spatial and spectral resolutions has been acquired. According to the rough guideline given in (Navulur, 2006), the spatial resolution of remote sensing imagery can be classified as four categories, including: (i) low or coarse resolution as pixels with ground sampling distance (GSD) of $30 \mathrm{~m}$ or greater, (ii) medium resolution as GSD in the range of $2.0-30 \mathrm{~m}$, (iii) high resolution as GSD in the range of $0.5-2.0 \mathrm{~m}$, and (iv) very high resolution as GSD $<0.5 \mathrm{~m}$.

Much work has been carried out to detect vegetation by using these various satellite images. AVHRR imagery with $1 \mathrm{~km}$ GDS multispectrial data from NOAA satellite series has mainly used for vegetation mapping at global, continental or national scale(Atzberger \& Rembold, 2013; Pan et al., 2015; Peng et al., 2012). The first Landsat satellite was launched in 1972. The Landsat might have the longest history for vegetation mapping. Landsat images with GSD of 30 meters have been applied for vegetation mapping mainly at regional scales (DomaÇ \& Süzen, 2006; Knight, Tindall, \& Wilson, 2009; Liu \& Yang, 2013; Salas, Boykin, \& Valdez, 2016; Tanser \& Palmer, 2000). IKONOS was launched in 1999 and was the first satellite to collect publicly available high-resolution imagery at 1 and $4 \mathrm{~m}$ resolution. IKONOS imageries have also been applied for local vegetation index calculation and mapping (Allbed,
Kumar, \& Aldakheel, 2014; Anchang, Ananga, \& Pu, 2016; Hui, Linhai, Liming, \& Qiuming, 2016; Laidler, Treitz, \& Atkinson, 2008). Some very high resolution aerial photos with $0.5 \mathrm{~m}$ or less GSD have also been used for mapping various local vegetation land covers (Macfarlane, McGinty, Laub, \& Gifford, 2017; Mora, Vieira, Pina, Lousada, \& Christiansen, 2015; Sankaran, Quirós, Knowles, \& Knowles, 2017; Su et al., 2016; Xiaoxiao \& Shao, 2014).

Several of the existing studies have shown the potential of satellite images in mapping honeysuckle in forest understories. Wilfong et al. (Wilfong et al., 2009) used Landsat images to explore the spectral differences between honeysuckle and deciduous trees in southwestern Ohio, USA. They confirmed that there was an approximately 4-week period (Nov. 4 to Nov. 30) when honeysuckle showed distinguishably higher normalized difference vegetation index (NDVI) than trees. Resasco et al. (Resasco et al., 2007) also explored the Landsat imagery in early spring but found that it was unlikely useful in this period, because spring ephemeral herbs also greened up earlier. In both studies, the detected honeysuckle covers contain high noises. Due to low spatial resolution of the Landsat data (30 meter GSD), their study results are highly affected by complex plant composition in tree canopy and herbaceous species on the ground. Therefore, the accuracy of the final results on honeysuckle distribution in both studies is limited. 
Several previous studies have explored the effects of using high-resolution satellite imagery in detecting invasive plants, such as invasive weeds, Sericea Lespedeza (C. Wang, Zhou, \& Palm, 2008) and cutleaf teasel (C. Wang, Bentivegna, Smeda, \& Swanigan, 2010). Some other research has also investigated applications of high resolution aerial imagery for invasive plant monitoring (Jones, Pike, Thomas, \& Murphy, 2011; Perroy, Sullivan, $\&$ Stephenson, 2017; Rivas-Torres, Benítez, Rueda, Sevilla, \& Mena, 2018).

Meanwhile, GPHC has made great effort on monitoring and managing the parks' non-native plants, which provides valuable ground truthing data for image processing and analysis for honeysuckle mapping. In this project, we will integrate these techniques and ground observations with the unique phenology features to document the current status of honeysuckle in the test field in GPHC parks.

\section{Methodology}

A WorldView-2 image covering our study area was ordered and on Nov. $9^{\text {th }} 2013$ was acquired. Field data on the densities of six various honeysuckle distribution sampling sites were collected in Nov 2013. Half of the sites were used for the computer training purpose and the other half were used for the validation purpose. The original WorldView-2 image was processed and classified into two major honeysuckle types and other land use types. The classification map was validated with use of the field data and high resolution aerial photos covering the same area. The flowchart of the methodology is shown in Figure 4.

\subsection{Image Data Acquisition}

In this study, we decided to use WorldView-2 satellite images (WorldView-2 http: // www. landinfo. com/ World View2. htm) for our study purpose. There are two major reasons for us to use WorldView-2. The first reason is that
WorldView-2 contains all spectral bands that we need to detect vegetation, that is, red band and near infrared band. The second reason is that it has high spatial resolution, 2 meter. This is way much better than TM images with 30 meter resolution.

WorldView-2 has 8 multispectral bands. Among them, four of them are regular bands, including blue band (spectral range $450 \mathrm{~nm}-510 \mathrm{~nm}$ ), green band (spectral range $510 \mathrm{~nm}-580 \mathrm{~nm}$ ), red band (spectral range $630 \mathrm{~nm}$ $690 \mathrm{~nm}$ ) and a near infrared band (spectral range $770 \mathrm{~nm}$ $895 \mathrm{~nm}$ ). The other four are new bands, including costal band (spectral range $400 \mathrm{~nm}-450 \mathrm{~nm}$ ), yellow band (spectral range $585 \mathrm{~nm}-625 \mathrm{~nm}$ ), red edge band (spectral range $705 \mathrm{~nm}-745 \mathrm{~nm}$ ), and another near infrared band (spectral range $860 \mathrm{~nm}-1040 \mathrm{~nm}$ ).

We ordered WorldView-2 image in the spring 2013. The WorldView-2 image was acquired on Nov. $9^{\text {th }}$ 2013. It was a sunny day and no cloud cover on the image.

\subsection{Field Data Collection}

Field data on honeysuckle density were collected in the study area on Nov. 8, 9 and 11, 2013. In total, honeysuckle density data of six sampling sites were collected. Half of the field data collected was used as training data in the image processing process for the computer to learn what kind of image pixels were honeysuckle. The rest of them were used to validate the image processing results with the high resolution aerial photos.

Each of these 6 sampling sites was 10 meter long and 10 meter wide squares. We had expected that the six sites should include two high-density honeysuckle sites (with honeysuckle coverage density $>60 \%$, named as $\mathrm{H} 1$ and $\mathrm{H} 2$ ), two medium-density sides (with honeysuckle density between $30 \%$ and $60 \%$, named as M1 and M2), and two low density sites (with honeysuckle density $<30 \%$, named as L1 and L2). These six sites are shown in Figure 5.

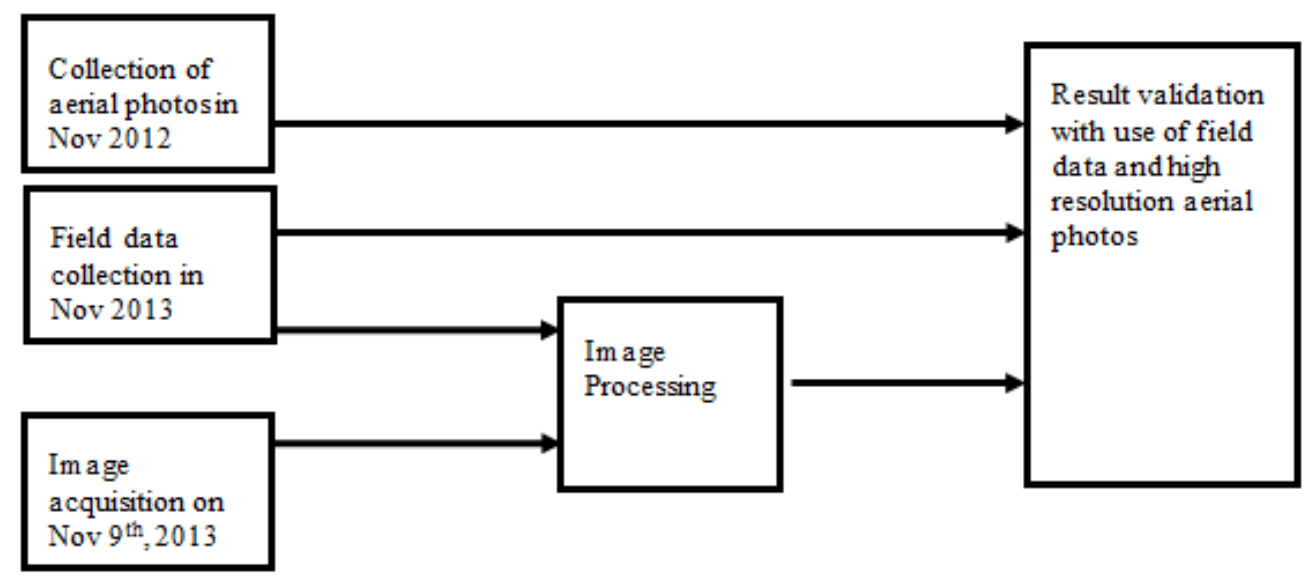

Figure 4. Flowchart of the Methodology 


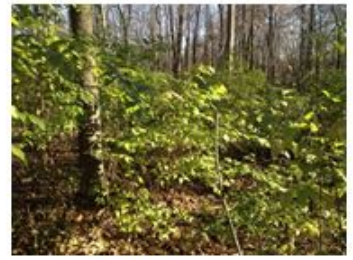

$\mathrm{H} 1$

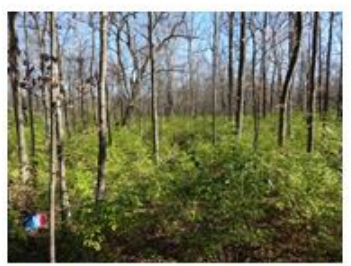

$\mathrm{H} 2$

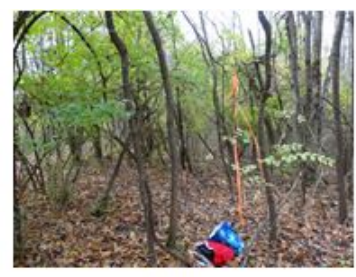

M1

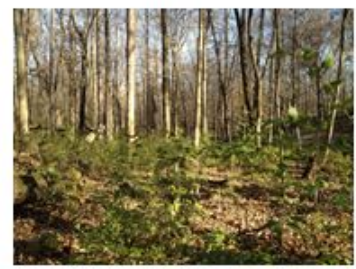

M2

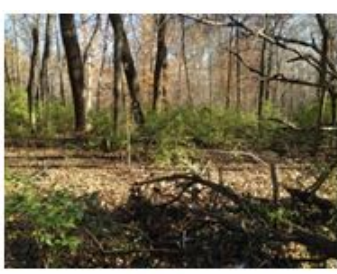

L1

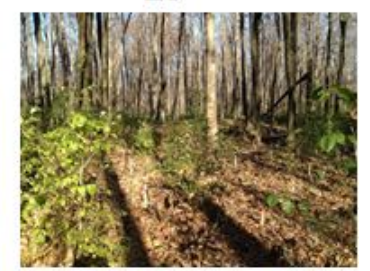

L2

Figure 5. Six Sampling Sites

Each sampling site was divided into 25 equal-size square cells ( 2 meter by 2 meter) (Figure 6 (A)). We measured each cell's honeysuckle density by use of the line-intersect method (Canfield, 1941), that is, the honeysuckle density of a line was calculated with the following equation:

Honeysuckle density on a line $=$ the total length of honeysuckle on that line / the total length of that line

We randomly selected 3 lines on each cell (Figure 6 (B)), which were parallel to north-south edges of that cell, and then measured the honeysuckle density of each line. The average honeysuckle density of the three lines was used to represent the honeysuckle density of that cell.

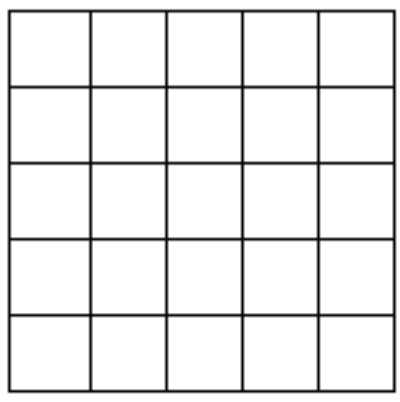

(A)

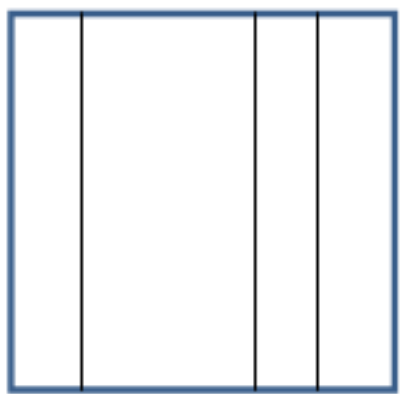

(B)

Figure 6. Sample Site Division (A) and Density Measurement Lines (B)

However, not all the final honeysuckle density data of each site was as expected. The honeysuckle density results are given in Table 1 below. The results show that only $\mathrm{L} 1$ and $\mathrm{H} 2$ are very representative low/high honeysuckle density sites, while the others are not. $60 \%$ of M2 site are high density cells, and $56 \%$ of M2 are low density cells. None of them was representative medium density honeysuckle sites. L2 has one quarter of medium or high density cells and H1 has about half of low/medium density cells.

Table 1. Density Distribution of 6 Honeysuckle Sampling Sites in 2013

\begin{tabular}{|c|c|c|c|c|c|c|}
\hline \multirow{2}{*}{$\begin{array}{c}\text { Sampling Site } \\
\text { Name }\end{array}$} & \multicolumn{2}{|c|}{$\begin{array}{c}\text { Low Density Cells } \\
\text { (Honeysuckle density }<30 \%)\end{array}$} & \multicolumn{2}{|c|}{$\begin{array}{c}\text { Medium Density Cells (Honeysuckle } \\
\text { density between } 30 \% \text { and } 60 \% \text { ) }\end{array}$} & \multicolumn{2}{|c|}{$\begin{array}{c}\text { High Density Cells (Honeysuckle } \\
\text { density above } 60 \% \text { ) }\end{array}$} \\
\hline & $\begin{array}{l}\text { Total Number of Cells } \\
\text { (out of } 25 \text { cells) }\end{array}$ & $\%$ & $\begin{array}{c}\text { Total Number of Cells (out of } 25 \\
\text { cells) }\end{array}$ & $\%$ & $\begin{array}{c}\text { Total Number of Cells (out } \\
\text { of } 25 \text { cells) }\end{array}$ & $\%$ \\
\hline L1 & 24 & 96 & 0 & 0 & 1 & 4 \\
\hline L2 & 18 & 72 & 6 & 24 & 1 & 4 \\
\hline M1 & 3 & 12 & 7 & 28 & 15 & 60 \\
\hline M2 & 14 & 56 & 8 & 32 & 3 & 12 \\
\hline H1 & 4 & 16 & 7 & 28 & 14 & 56 \\
\hline $\mathrm{H} 2$ & 1 & 4 & 4 & 16 & 20 & 80 \\
\hline
\end{tabular}


Finally, we decided to use only two classes of honeysuckle, including the low density class and the medium/high density class. The sampling sites are re-organized as below in Table 2. L1, H1 and $\mathrm{H} 2$ were to be used as training sites for the low density class and the medium/high density classes. The rest of sites were to be used for validation later.

Table 2. 6 Honeysuckle Sampling Sites for Training and Validation

\begin{tabular}{|c|c|c|c|c|c|}
\hline \multirow{2}{*}{$\begin{array}{l}\text { Sampling Site } \\
\text { Name }\end{array}$} & \multicolumn{2}{|c|}{$\begin{array}{c}\text { Low Density Cells (Honeysuckle } \\
\text { density }<30 \% \text { ) }\end{array}$} & \multicolumn{2}{|c|}{$\begin{array}{l}\text { Medium/high Density Cells (Honeysuckle } \\
\text { density above } 30 \%\end{array}$} & \multirow{2}{*}{$\begin{array}{c}\text { Use for } \\
\text { Training/Validation }\end{array}$} \\
\hline & $\begin{array}{l}\text { Total Number of Cells (out of } \\
25 \text { cells) }\end{array}$ & $\%$ & Total Number of Cells (out of 25 cells) & $\%$ & \\
\hline L1 & $\mathrm{C}_{\mathrm{C}}$ & 96 & 1 & 4 & $\begin{array}{l}\text { Training for low } \\
\text { density }\end{array}$ \\
\hline L2 & 18 & 72 & 7 & 28 & Validation \\
\hline M1 & 3 & 12 & 22 & 88 & Validation \\
\hline M2 & 14 & 56 & 11 & 44 & Validation \\
\hline H1 & 4 & 16 & 21 & 84 & $\begin{array}{l}\text { Training site for high } \\
\text { density }\end{array}$ \\
\hline $\mathrm{H} 2$ & 1 & 4 & 24 & 96 & $\begin{array}{l}\text { Training site for high } \\
\text { density }\end{array}$ \\
\hline
\end{tabular}

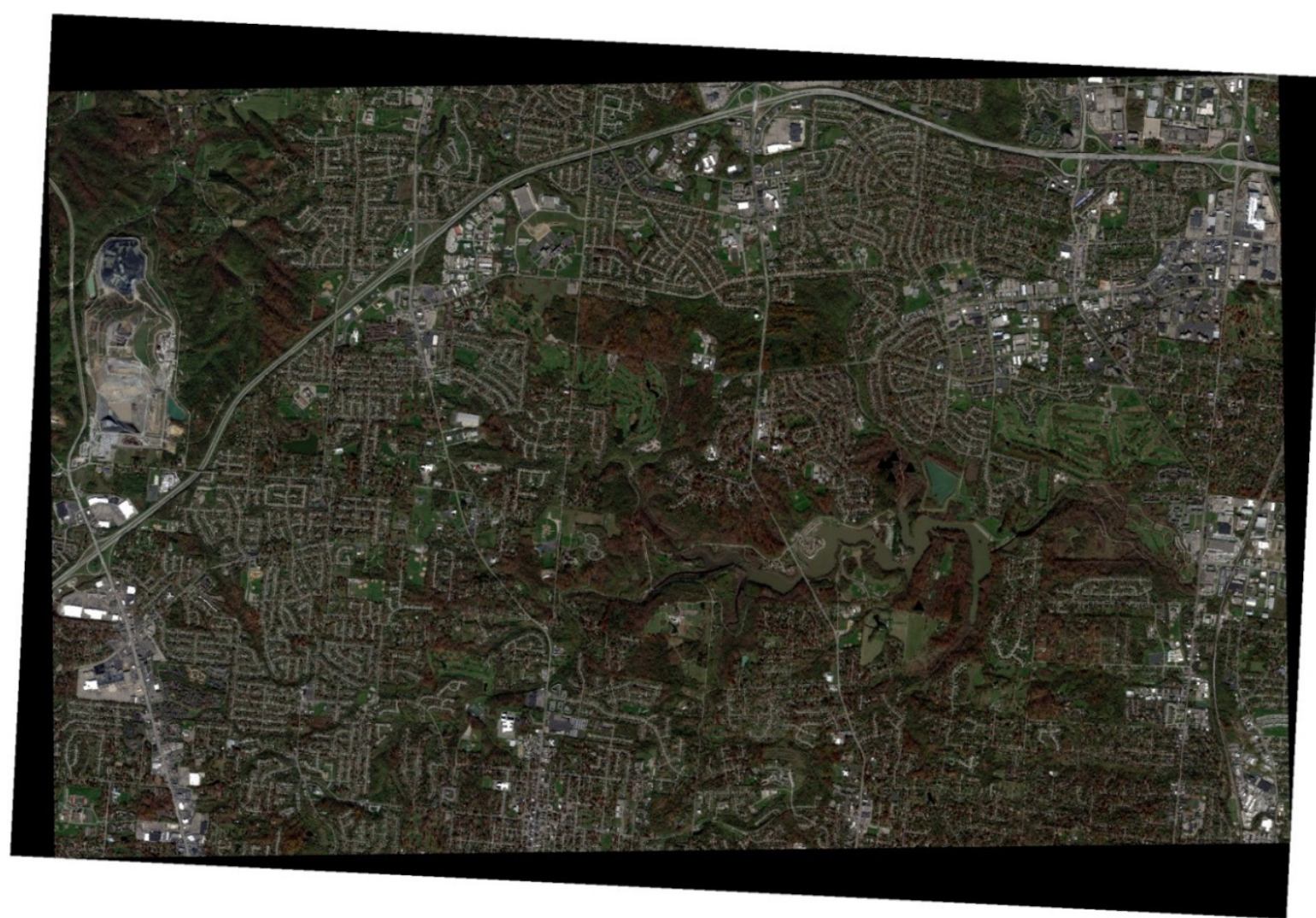

Figure 7. Original Image

\subsection{Image Data Processing}

The original World-View2 image (Figure 7) is shown below. It has some geometric errors due to the position of the satellite sensor and the earth's terrain. In addition, the original data in each pixel is raw data, containing information not only the reflected or emitted radiation from the earth surface, but also the radiation scattered or emitted by the atmosphere. In our case, we are interested in the surface reflectance only. Therefore, we need to remove these errors before directly using the image for honeysuckle mapping.
The image process went through the following steps. At first, the image was rectified in order to remove distortion across the image caused by distortions from the satellite sensor and the earth's terrain. Second, the rectified image was then converted into electromagnetic reflectance. This step was used to remove the radiation scattered or emitted by the atmosphere from the pixels in the rectified image. Third, the reflectance image finally needs to be classified into several land use types, including low density honeysuckle area, medium/high density honeysuckle area and other land use types. 
The classification method that we used is the Maximum Likelihood Classification (MLC) method, which is one of the commonly used supervised classification methods. The MLC method needs to have training data for each class. Training data is used in the MLC classification process to characterize each class. This method calculates the probability that each pixel in the image belongs to each class. Finally, each pixel is classified as the class that has the highest probability.

During the classification process, the site, L1, was used as the training data for the low density honeysuckle area class. The sites, $\mathrm{H} 1$ and $\mathrm{H} 2$, were used as training data for the medium/high density honeysuckle area class. Several training sites for the water/wet land class, the bare soil/construction class, and the grass/crop class were visually selected from the image for the classification process.

\section{Findings}

The final classification result from the MLC method is given in Figure 8. It shows various general land use types (including the grass/crop class, the bare soil/construction class and the water/wet land class) and two honeysuckle classes (including the low density class, and the medium/high density class).

To validate our honeysuckle mapping result accuracy, at first, we checked all our 6 sampling sites, including all training sites and validation sites. We calculated the honeysuckle coverage rate of low density area and that of medium/high density area for each site in the ground measurement and those two rates in the image. We also compared the coverage rate difference for each class in the ground measurement and in the image. See the results in Table 3 .

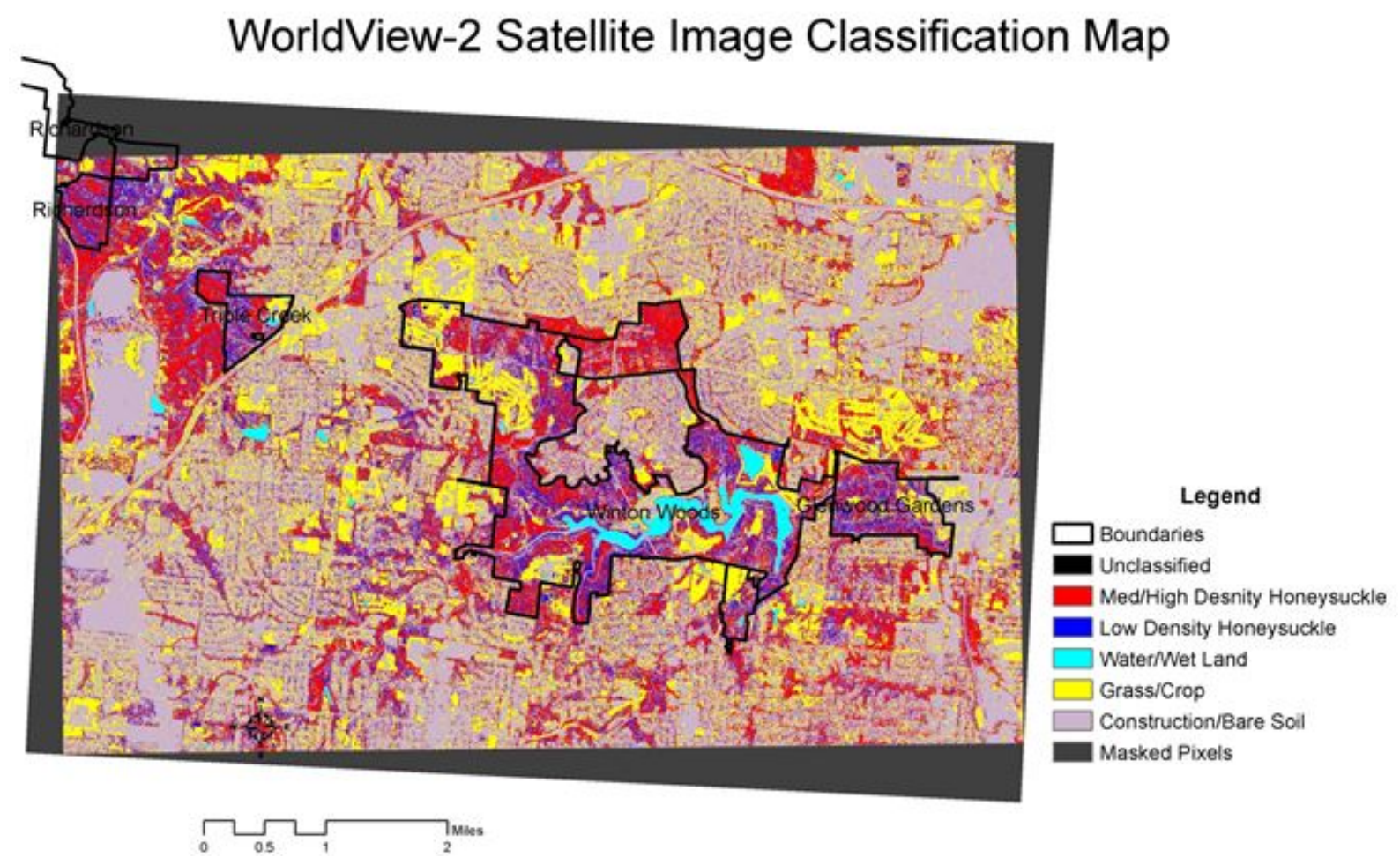

(In the map above, blue and red pixels represents low and medium/high density honeysuckle areas respectively)

Figure 8. Honeysuckle Distribution Map in the Study Area 
Table 3. Coverage Percentage in Honeysuckle Sampling Sites in 2013

\begin{tabular}{|c|c|c|c|c|c|c|c|}
\hline $\begin{array}{l}\text { Samplin } \\
\text { g Site } \\
\text { Name }\end{array}$ & $\begin{array}{l}\text { Site on Image (where the } \\
\text { black polygon is the site } \\
\text { boundary; blue and red } \\
\text { pixels are low and } \\
\text { medium/high density } \\
\text { classes) }\end{array}$ & $\begin{array}{l}\text { Low Density } \\
\text { Cell Rate in } \\
\text { the Ground } \\
(\%)\end{array}$ & $\begin{array}{c}\text { Low } \\
\text { Density Cell } \\
\text { Rate in the } \\
\text { Image }(\%)\end{array}$ & $\begin{array}{c}\text { Low } \\
\text { Density Cell } \\
\text { Rate } \\
\text { Difference } \\
\text { between } \\
\text { Ground and } \\
\text { Image (\%) } \\
\end{array}$ & $\begin{array}{l}\text { Medium/hig } \\
\text { h Density } \\
\text { Cell Rate in } \\
\text { the Ground } \\
\quad(\%)\end{array}$ & $\begin{array}{l}\text { Medium/Hig } \\
\text { h Density } \\
\text { Cell Rate in } \\
\text { the Image } \\
\text { (\%) }\end{array}$ & $\begin{array}{l}\text { Medium/High } \\
\text { Density Cell } \\
\text { Rate } \\
\text { Difference } \\
\text { between } \\
\text { Ground and } \\
\text { Image }(\%) \\
\end{array}$ \\
\hline $\begin{array}{c}\text { L1 } \\
\text { (Trainin } \\
\text { g for low } \\
\text { density) }\end{array}$ & & 96 & 95 & +1 & 4 & 5 & -1 \\
\hline $\begin{array}{l}\text { L2(Valid } \\
\text { ation) }\end{array}$ & & 72 & 77 & +5 & 28 & 23 & -5 \\
\hline $\begin{array}{c}\text { M1(Vali } \\
\text { dation) }\end{array}$ & & 12 & 28 & +16 & 88 & 72 & -16 \\
\hline $\begin{array}{c}\text { M2 } \\
\text { (Validati } \\
\text { on) }\end{array}$ & & 56 & 48 & -8 & 44 & 52 & +8 \\
\hline $\begin{array}{l}\text { H1 } \\
\text { (Trainin } \\
\text { g for } \\
\text { medium/ } \\
\text { high } \\
\text { density) }\end{array}$ & & 16 & 8 & -8 & 84 & 92 & +8 \\
\hline $\begin{array}{l}\text { H2 (Train } \\
\text { ing for } \\
\text { medium/ } \\
\text { high } \\
\text { density) }\end{array}$ & & 4 & 0 & -4 & 96 & 100 & +4 \\
\hline
\end{tabular}

The results above show that the image mapping results for all the six sampling sites match with the ground measurement data pretty well. The image identification results for the three training sites (L1, H1 and H2) have the best matching with the ground measurement. The honeysuckle coverage rate difference between the ground measurement and the image result for each of the three training sites is pretty small, between $1 \%$ and $8 \%$. Two of the validation sites, L2 and M2, also have good matching results and their honeysuckle coverage rate difference for each class is between $5 \%$ and $8 \%$. Only the validation site, $\mathrm{M} 1$, has relatively larger coverage rate difference, $16 \%$, between the ground measurement and the image result.
In order to have better validation to our image results, we need to have more validation data. The Pictometry Online (https://www.eagleview.com/product/pictometry-imagery/) offers high resolution aerial photos covering our study area. We used some aerial photos taken on Nov 17, 2012 from their website to validate our satellite image mapping results. These aerial photos have 4 inch spatial resolution. From the website image, we can clearly see whether each area has honeysuckle (or green leaves) or not on each location. For example, our high density honeysuckle site H1 shows a lot of honeysuckle on the Pictometry aerial photo (Figure 9 (A) ), and the low density honeysuckle site L1 (Figure 9 (B) )does not show much green pixels on the photo. 
Pictometry Online 1.11.3

Welcome Margaret Minzner | Coverage | Logout

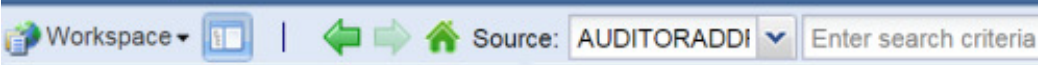

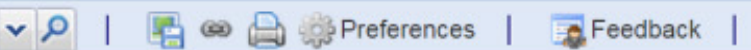

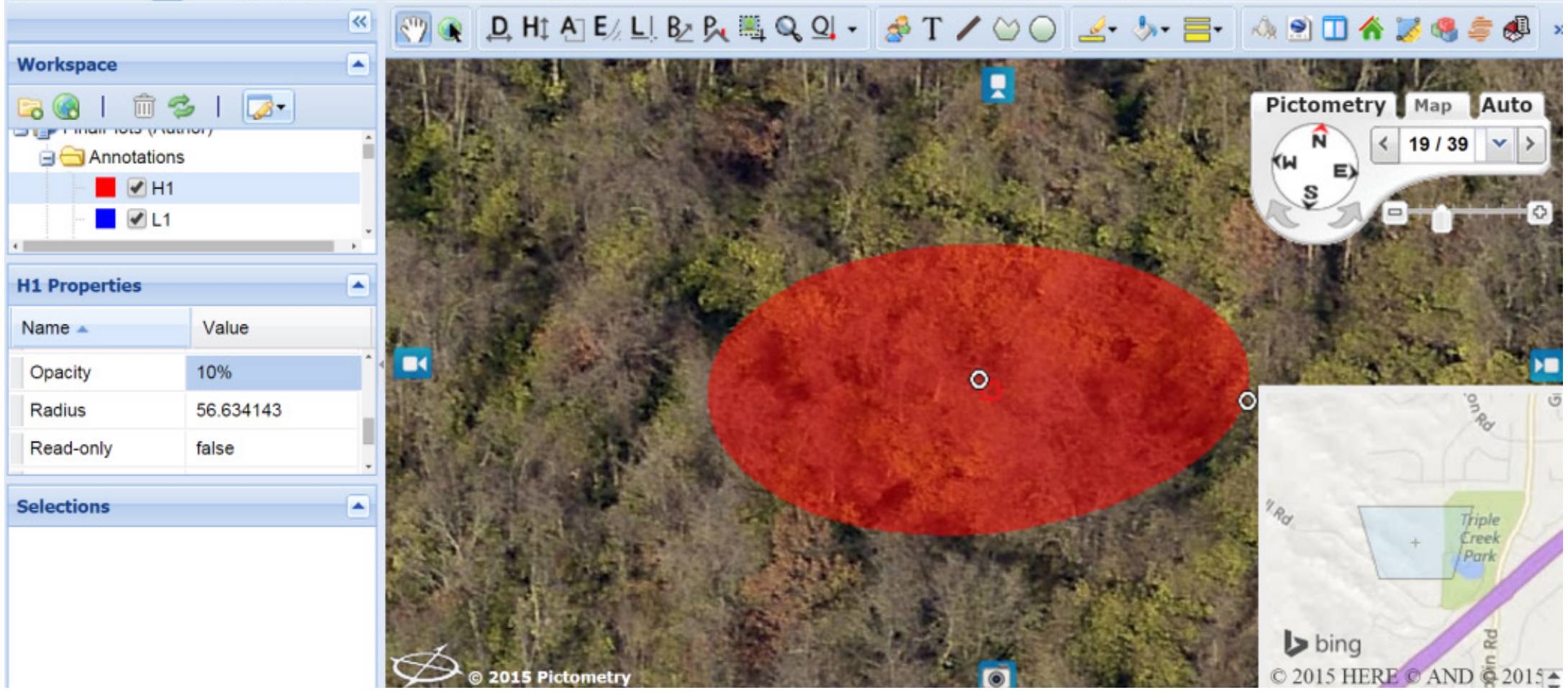

(A) Aerial Photo for High Density Honeysuckle Site H1 


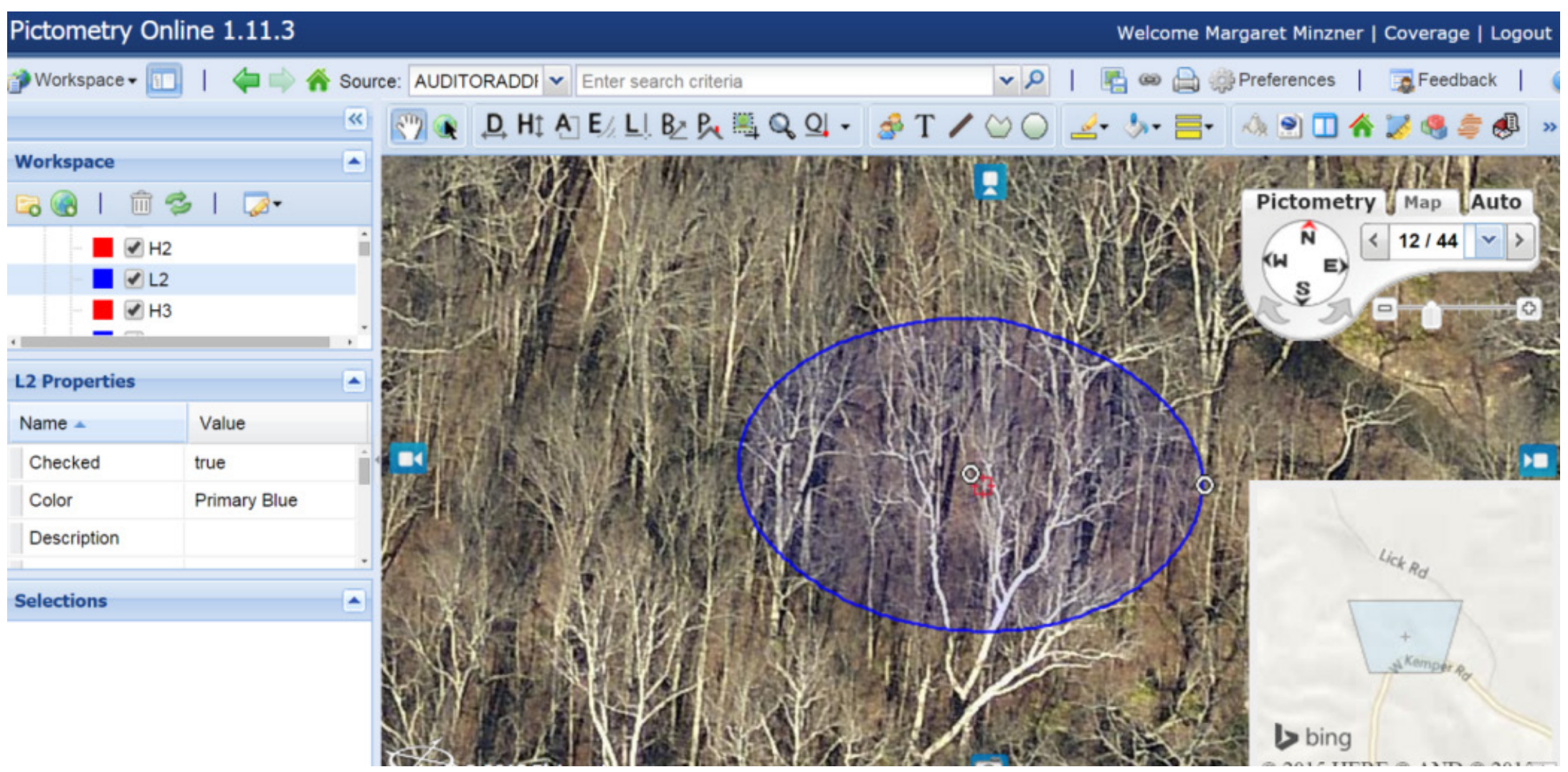

(B) Aerial Photo for Low Density Honeysuckle Site L1

Figure 9. Example Pictometry Aerial Photos for High Density Site H1(A) and Low Density Site L1 (B) 
Table 4. Validation Results from Aerial Photos Taken in Nov. 17, 2012

\begin{tabular}{|c|c|c|c|c|}
\hline & $\begin{array}{c}\text { Number of } \\
\text { Validation Sites on } \\
\text { Aerial Photos }\end{array}$ & $\begin{array}{c}\text { Number of Sites with } \\
\text { Correct Classification on } \\
\text { Image }\end{array}$ & $\begin{array}{c}\text { Number of Sites with } \\
\text { Close-to-Correct Classification } \\
\text { on Image }\end{array}$ & $\begin{array}{c}\text { Number of Sites with } \\
\text { Wrong Classification on } \\
\text { Image }\end{array}$ \\
\hline Low Density & 19 & 9 (Low density cell rate $>$ \\
$60 \%)$ & 6 (Low density cell rate $50 \%-$ & $60 \%)$ & $\begin{array}{c}4(\text { Low density cell rate } \\
30 \%-50 \%)\end{array}$ \\
\hline $\begin{array}{c}\text { Medium/High } \\
\text { Density }\end{array}$ & 20 & $\begin{array}{c}19 \text { (Medium/High density } \\
\text { cell rate }>60 \%)\end{array}$ & 1 (Medium/High cell rate $47 \%)$ & 0 \\
\hline
\end{tabular}

We visually selected 39 validation sites and each is larger than 20 meter by 20 meter. Our final validation result is shown in Table 4. Among these sites, 20 were visually identified as medium/high honeysuckle sites from the aerial photo image. 19 out of the 20 sites were correctly classified as medium/high density honeysuckle class on the satellite image because their medium/high density cell coverage rate in each site on the image are above $60 \%$. Only one site has $47 \%$ medium/high density pixels. The rest of 19 validation sites were visually identified as low honeysuckle density areas from the aerial photo. Among these 19 sites, 9 of them were correctly classified as the low density honeysuckle class on the image with $30 \%$ or less low density honeysuckle cell coverage; 6 of them have $50 \%$ to $60 \%$ low density cell coverage; 4 of them have $30 \%$ to $50 \%$ low density cell rate, which means each of these 4 sites has more than half of medium/high density honeysuckle cells.

\section{Discussion}

The validation results show some false positives in our mapping result. For example, among the 19 low density honeysuckle sites identified from the aerial photo, 4 of them show as medium/high density honeysuckle cells on the image. One cause of a false positives can be the presence of vegetation such as grasses, sedges or vines that are still green in the late fall when the satellite image was acquired. If an image cell covers both bare tree branches and other green vegetation, it is possible for the computer to mistakenly recognize the other green vegetation as honeysuckle's green leaves and classify such cells as medium/high density honeysuckle areas. In the future, we need to improve the classification process. For example, the texture of the other vegetation may look different from the honeysuckle bush texture on the image. We may use this texture difference in addition to the greenness of the cell to distinguish the regular tree from the honeysuckle bush.

The classification result really depends on the quality of training data. However, it was difficult to select perfect field sampling sites for training data. For example, of two honeysuckle sampling sites thought to be medium density, one of them turned out to be a high density honeysuckle area. In addition to the need for sampling sites to be representative of the class they belong to, they should also be fairly homogenous. Therefore, it is better that the honeysuckle distribution in each sampling site is evenly distributed. However, in practice, it is hard to find evenly distributed medium density honeysuckle density areas in the field. In the future, it would be better to remove the medium density class in consideration and focus on only the low density and high density classes. In addition, as satellite images with higher spatial resolutions are available, we can just focus on two classes, honeysuckle and trees (and non-honeysuckle bushes), in the large forest areas.

The number of field sampling sites in this study was limited. We had only three field sampling sites for the training purpose. The quality of the three training sites has the most impact on the quality of the final classification result. It would be better if we had more training sites so that the final result would not be biased by the training sites. Similarly, we had only three field sites for the validation purpose. The field sampling sites are better than the aerial photo sites for validation. In the aerial photo, we can see the scene of the woods only from above, which restricts view of the ground. If there were more field sampling sites for validation, it would be easier to explain why the low density sites were classified as the medium/high density class on the satellite image. In the future, we will need to prepare more field sampling sites for training and validation.

\section{Conclusions and Future Work}

This paper describes the method of using high-resolution satellite image, WorldView-2, to map out spatial distribution of invasive plants, honeysuckle in the HCGP park areas, in Ohio, USA. The mapping result demonstrates that the medium/high density honeysuckle area can be successfully identified from the image with our method. Our method needs to be further improved to recognize the low honeysuckle density areas because of some green plants underneath the woods or other reasons.

This study provides a quick method for local park managers to identify spatial distribution of honeysuckle. The study result will provide important information for understanding the status of wildlife habitats and for implementing site-specific management in parks and nature preserves.

The mapping result can help the local community to quickly identify honeysuckle spatial distribution location in large forest areas, and understand the status of wildlife 
habitats. This will help them to implement site-specific management plans, such as where to send staff to treat the honeysuckle, how many people should be allocated for each areas of honeysuckle, how long it will be expected to complete the honeysuckle treatment work, etc. In addition, if we can keep track of honeysuckle distribution in the forest continuous by using this method, it will be helpful for them to know how well their honeysuckle treatment methods work.

We have applied the MLC method to classify the cells in the image. This method directly uses the reflectance difference between classes to classify each cell in the image. According to previous studies(Singh, Chen, Smart, Gray, \& Meentemeyer, 2018; C. Wang et al., 2010; Cuizhen Wang, Lu, \& Haithcoat, 2007; C. Wang et al., 2008), various vegetation indices calculated from satellite images are helpful to distinguish green vegetation from other objects. In the future, we plan to test whether various normalized vegetation indices will be helpful to distinguish honeysuckle from other green vegetation and differentiate different honeysuckle density coverage levels.

\section{Acknowledgements}

This work is supported by Northern Kentucky University Faculty Summer Fellowship in 2013 and Faculty Project Grant in 2013. The authors would like to thank Jim Mundy, Amy Code, Nick Mercer and other GPHC staff for providing GIS data, collecting field data and aerial photo validation sites; Dusty Rhodes (Hamilton County Auditor) and Pictometry International for allowing us to use the Pictometry aerial photos for free; Dr. Richard Boyce for offering training on use of densitometer; Dr. Kristy Hopfensperger and Dr. Richard Boyce for discussing and suggesting density measurement.

\section{REFERENCES}

[1] Allbed, A., Kumar, L., \& Aldakheel, Y. Y. (2014). Assessing soil salinity using soil salinity and vegetation indices derived from IKONOS high-spatial resolution imageries: Applications in a date palm dominated region. Geoderma, 230-231, 1-8.doi:10.1016/j.geoderma.2014.03. 025

[2] Anchang, J. Y., Ananga, E. O., \& Pu, R. (2016). An efficient unsupervised index based approach for mapping urban vegetation from IKONOS imagery. International Journal of Applied Earth Observation \& Geoinformation, 50, 211-220. doi: 10.1016/j.jag.2016.04.001

[3] Asrar, G., Fuchs, M., Kanemasu, E. T., \& Hatfield, J. L. (1984). Estimating Absorbed Photosynthetic Radiation and Leaf Area Index from Spectral Reflectance in Wheat1. Agronomy Journal, 76(2), 300-306. doi: 10.2134/agronj19 $84.00021962007600020029 \mathrm{x}$
[4] Atzberger, C., \& Rembold, F. (2013). Mapping the Spatial Distribution of Winter Crops at Sub-Pixel Level Using AVHRR NDVI Time Series and Neural Nets. Remote Sensing, 5(3), 1335-1354. doi: 10.3390/rs5031335

[5] Beeri, O., Phillips, R., Hendrickson, J., Frank, A. B., \& Kronberg, S. (2007). Estimating forage quantity and quality using aerial hyperspectral imagery for northern mixed-grass prairie. Remote Sensing of Environment, 110(2), 216-225. doi:https://doi.org/10.1016/j.rse.2007.02.027

[6] Canfield, R. H. (1941). Application of the line interception method in sampling range vegetation. Journal of Forestry, 39.

[7] DomaÇ, A., \& Süzen, M. L. (2006). Integration of environmental variables with satellite images in regional scale vegetation classification. International Journal of Remote Sensing, 27(7), 1329-1350. doi: 10.1080/01431160 500444806

[8] Gallo, K. P., \& Daughtry, C. S. T. (1986). Techniques for Measuring Intercepted and Absorbed Photosynthetically Active Radiation in Corn Canopies1. Agronomy Journal, 78(4), 752-756. doi: 10.2134/agronj1986.00021962007800 040039x

[9] Huete, A. R. (2004). REMOTE SENSING FOR ENVIRONMENTAL MONITORING. In J. F. Artiola, I. L. Pepper, \& M. L. Brusseau (Eds.), Environmental Monitoring and Characterization (pp. 183-206). Burlington: Academic Press.

[10] Hui, L., Linhai, J., Liming, W., \& Qiuming, C. (2016). Improved Pansharpening with Un-Mixing of Mixed MS Sub-Pixels near Boundaries between Vegetation and Non-Vegetation Objects. Remote Sensing, 8(2), 1-24. doi: $10.3390 /$ rs 8020083

[11] Jensen, J. R. (2006). Remote Sensing of the Environment: An Earth Resource Perspective: Pearson.

[12] Jones, D., Pike, S., Thomas, M., \& Murphy, D. (2011). Object-Based Image Analysis for Detection of Japanese Knotweed s.l. taxa (Polygonaceae) in Wales (UK). Remote Sensing, 3(2), 319-342. doi: 10.3390/rs3020319

[13] Knight, A. W., Tindall, D. R., \& Wilson, B. A. (2009). A multitemporal multiple density slice method for wetland mapping across the state of Queensland, Australia. International Journal of Remote Sensing, 30(13), 3365-3392. doi: 10.1080/01431160802562180

[14] Laidler, G. J., Treitz, P. M., \& Atkinson, D. M. (2008). Remote Sensing of Arctic Vegetation: Relations between the NDVI, Spatial Resolution and Vegetation Cover on Boothia Peninsula, Nunavut. Arctic, 61(1), 1-13.

[15] Liu, T., \& Yang, X. (2013). Mapping vegetation in an urban area with stratified classification and multiple endmember spectral mixture analysis. Remote Sensing of Environment, 133, 251-264. doi:10.1016/j.rse.2013.02.020

[16] Luken, J. O. (1988). Population Structure and Biomass Allocation of the Naturalized Shrub Lonicera maackii (Rupr.) Maxim. in Forest and Open Habitats. American Midland Naturalist, 119(2), 258-267. doi:10.2307/2425809

[17] Macfarlane, W. W., McGinty, C. M., Laub, B. G., \& Gifford, S. J. (2017). High - resolution riparian vegetation 
mapping to prioritize conservation and restoration in an impaired desert river. Restoration Ecology, 25(3), 333-341.

[18] Mora, C., Vieira, G., Pina, P., Lousada, M., \& Christiansen, H. H. (2015). Land cover classification using high-resolution aerial photography in Adventdalen, Svalbard. Geografiska Annaler. Series A: Physical Geography, 97(3), 473-488. doi: 10.1111/geoa.12088

[19] Navulur, K. (2006). Multispectral Image Analysis Using the Object-Oriented Paradigm. New York: CRC Press.

[20] Pan, Z., Huang, J., Zhou, Q., Wang, L., Cheng, Y., Zhang, H., . . L Liu, J. (2015). Mapping crop phenology using NDVI time-series derived from $\mathrm{HJ}-1 \mathrm{~A} / \mathrm{B}$ data. International Journal of Applied Earth Observation \& Geoinformation, 188-197. doi:10.1016/j.jag.2014.08.011

[21] Peng, D., Zhang, B., Liu, L., Chen, D., Fang, H., \& Hu, Y. (2012). Seasonal dynamic pattern analysis on global FPAR derived from AVHRR GIMMS NDVI. International Journal of Digital Earth, 5(5), 439-455. doi: 10.1080/1753 8947.2011.596579

[22] Perroy, R. L., Sullivan, T., \& Stephenson, N. (2017). Assessing the impacts of canopy openness and flight parameters on detecting a sub-canopy tropical invasive plant using a small unmanned aerial system. ISPRS Journal of Photogrammetry \& Remote Sensing, 125, 174-183. doi:10.1016/j.isprsjprs.2017.01.018

[23] Pimentel, D., Lach, L., Zuniga, R., \& Morrison, D. (2000). Environmental and Economic Costs of Nonindigenous Species in the United States, 53.

[24] Resasco, J., Hale, A. N., Henry, M. C., \& Gorchov, D. L. (2007). Detecting an invasive shrub in a deciduous forest understory using late-fall Landsat sensor imagery. International Journal of Remote Sensing, 28(16), 3739-3745. doi: 10.1080/01431160701373721

[25] Rivas-Torres, G. F., Benítez, F. L., Rueda, D., Sevilla, C., \& Mena, C. F. (2018). A methodology for mapping native and invasive vegetation coverage in archipelagos. Progress in Physical Geography, 42(1), 83-111. doi: 10.1177/0309133 317752278

[26] Salas, E. A. L., Boykin, K. G., \& Valdez, R. (2016). Multispectral and Texture Feature Application in Image-Object Analysis of Summer Vegetation in Eastern Tajikistan Pamirs. Remote Sensing, 8(1), 1-20. doi:10.3390/rs 8010078

[27] Sankaran, S., Quirós, J., Knowles, N., \& Knowles, L. (2017). High-Resolution Aerial Imaging Based Estimation of Crop Emergence in Potatoes. American Journal of Potato Research, 94(6), 658-663.

[28] Singh, K. K., Chen, Y.-H., Smart, L., Gray, J., \& Meentemeyer, R. K. (2018). Intra-annual phenology for detecting understory plant invasion in urban forests. ISPRS Journal of Photogrammetry and Remote Sensing, 142, 151-161. doi:10.1016/j.isprsjprs.2018.05.023

[29] Su, Y., Guo, Q., Collins, B. M., Fry, D. L., Hu, T., \& Kelly, M. (2016). Forest fuel treatment detection using multi-temporal airborne lidar data and high-resolution aerial imagery: a case study in the Sierra Nevada Mountains, California. International Journal of Remote Sensing, 37(14), $3322-3345$
[30] Tanser, F., \& Palmer, A. R. (2000). Vegetation mapping of the Great Fish River basin, South Africa: Integrating spatial and multi-spectral remote sensing techniques. Applied Vegetation Science, 3(2), 197-204. doi:10.2307/1478998

[31] Wang, C., Bentivegna, D. J., Smeda, R. J., \& Swanigan, R. E. (2010). Comparing multispectral and hyperspectral classifiers for mapping cut-leaved teasel in highway environments. Photogrammetric Engineering and Remote Sensing, 76, 567-575.

[32] Wang, C., Lu, Z., \& Haithcoat, T. L. (2007). Using Landsat images to detect oak decline in the Mark Twain National Forest, Ozark Highlands. Forest Ecology and Management, 240(1), 70-78. doi: 10.1016/j.foreco.2006.12.007

[33] Wang, C., Zhou, B., \& Palm, H. L. (2008). Detecting invasive Sericea Lespedeza (Lespedeza cuneata) in Mid-Missouri pastureland using hyperspectral imagery. Environment Management, 41(6), 853-862.

[34] Wilfong, B. N., Gorchov, D. L., \& Henry, M. C. (2009). Detecting an Invasive Shrub in Deciduous Forest Understories Using Remote Sensing. Weed Science, 57(5), 512-520. doi:10.1614/WS-09-012.1

[35] Xiaoxiao, L., \& Shao, G. (2014). Object-Based Land-Cover Mapping with High Resolution Aerial Photography at a County Scale in Midwestern USA. Remote Sensing, 6(11), 11372-11390. doi:10.3390/rs61111372 